doi: $10.19090 / \mathrm{i} .2015 .26 .37-45$

UDC: $355.1(398)$

ORIGINAL SCIENTIFIC PAPER

Received: 30 June 2015

Accepted: 1 October 2015

\author{
SNEŽANA FERJANČIĆ \\ University of Belgrade, Faculty of Philosophy \\ sferjanc@f.bg.ac.rs \\ THE ALA PANNONIORUM \\ IN THE ARMY OF ILLYRICUM*
}

\begin{abstract}
The province of Illyricum, established shortly after Octavian's Illyrian war and divided into Illyricum Superius (Dalmatia) and Illyricum Inferius (Pannonia) during or after the Pannonian-Dalmatian Rebellion, was garrisoned by several legions and various auxiliary regiments. The list of auxilia includes an ala Pannoniorum. Epigraphic evidence from Dalmatia and Pannonia provides some information on its relocation, as well as on its recruitment. Under Augustus, the regiment was in Dalmatia. It was relocated to Pannonia ca. 15 AD. At the beginning of Vespasian's reign, the ala Pannoniorum was transferred to Moesia Inferior. Its return to the Pannonian section of the Danubian limes is dated after the Marcommanic War of Marcus Aurelius. Belonging to the army of Pannonia Inferior, the unit was probably stationed in the fortress of Cusum. Epigraphic evidence allows us to glimpse certain patterns of its recruitment during the first sojourn in Illyricum. It appears that it was conscripted among the bellicose tribes of the Iberian Peninsula and the indigenous population of the southern Pannonia.
\end{abstract}

Keywords: Illyricum, Dalmatia, Pannonia, ala Pannoniorum, recruitment, Spaniards, Pannonians.

$\mathrm{T}$

The province of Illyricum, encompassing the vast region between the Danube and the Adriatic Sea, was established shortly after Octavian's Illyrian war (35-33 BC). During the Pannonian-Dalmatian rebellion (6-9 AD), or immediately after its suppression, it was divided into two separate administrative units, known as Illyricum Superius (i. e. Dalmatia) and Illyricum Inferius (i. e. Pannonia). ${ }^{1}$ The army of Illyricum consisted of several legions and numerous auxiliary units, including the ala Pannoniorum. The aim of this paper would be to examine its relocation and the patterns of its recruitment.

\footnotetext{
* The following abbreviations were used in the text and in the list of references: AE=L'année épigraphique, Paris.; $C I L=$ Corpus inscriptionum Latinarum, Berlin; $O P E L=$ Onomasticon provinciarum Europae Latinarum I-IV, Budapest/Wien, 1994-2002; RE=Realencyclopädie der classischen Altertumswissenschaft, Stuttgart; RIU=Die römische Inschriften Ungarns I-VI, Budapest/Amsterdam/Bonn, 1972-2001.

${ }^{1}$ On the establishment of Illyricum see Dzino 2010: 119. On the date of its division see Mócsy 1962: 583; J. J. Wilkes 1969: 95; Papazoglu 2007: 264; Dzino 2010: 137.
} 
Inscriptions mentioning soldiers and officers of the ala Pannoniorum have been discovered at various locations in Dalmatia and Pannonia. They form two distinct groups from a chronological point of view. Seven monuments belong to the pre-Flavian period. A fragmentary epitaph of Cloutius, son of Clutamus, was found in Salona in Dalmatia and dated to the reign of Augustus (CIL III 2016=8577). ${ }^{2}$ The funerary stelae of the regiment's soldiers from Pannonia, found in Peresznye (RIU 216, 217), ${ }^{3}$ Györ (RIU 255, 256, 258) and Deutsch Altenburg ( $A E$ 1997, 1251) respectively, belong to the reign of the JulioClaudian dynasty. The names of the deceased soldiers in nominative and the regiment's title in ablative are characteristic for the pre-Flavian period. ${ }^{4}$ The second group consists of three inscriptions found in Pannonia Inferior. They are dated to the end of the second century $\mathrm{AD}$ or to the beginning of the third century $\mathrm{AD}$. A fragmentary epitaph of a soldier named Crispinianus was discovered in the vicinity of the village of Páty, on the territory of Aquincum (RIU 1326). Two votive monuments were found in the south-eastern reaches of the province. An altar erected by the decurion Cogitatus to a deity whose name had not been preserved was found in Belegiš (CIL III 15138/3). Acumincum (modern Slankamen) has yielded a statue of Jupiter Dolichenus. It was dedicated by a decurion Aurelius Iustianus and a duplicarius Ulpius Silvinianus (CIL III 3252=10241). ${ }^{5}$

Considering the adduced epigraphic evidence, the history of the ala Pannoniorum in Illyricum is reconstructed as follows. At first, during Augustus' reign, it was garrisoned in Dalmatia, where it probably participated in the suppression of the Pannonian-Dalmatian Revolt. The exact location of its fortress remains unknown. Perhaps it should be sought in the vicinity of Salona, since the only inscription mentioning the regiment was discovered in that colony (CIL III 2016=8577). At the beginning of Tiberius' reign, ca. $15 \mathrm{AD}$, the ala Pannoniorum was transferred to Pannonia. ${ }^{6}$ It garrisoned the fortress at Strebersdorf, $4 \mathrm{~km}$ from Peresznye, the find-spot of the two tombstones of its soldiers (RIU 216, 217). Recent archaeological excavations at the site have shown that the earliest camp was constructed during Tiberius' reign. ${ }^{7}$ The relocation of the ala Pannoniorum from Dalmatia to Pannonia should be regarded as one of the measures undertaken for ensuring a more efficient protection of the road system in Pannonia. It guarded a section of the famous Amber road, a vital trade route that connected Aquileia in northern Italy with Carnuntum on the Danube. ${ }^{8}$ In the second half of Tiberius' reign, however, the ala Pannoniorum garrisoned the fortress of Arrabona. Its presence there is attested by three funerary stelae found in modern Györ (RIU 255, 256, 258). ${ }^{9}$ The earliest timber-earth fort at the site was erected

\footnotetext{
${ }^{2}$ Holder 1980: $283, \mathrm{n}^{\circ} 621$.

${ }^{3}$ In $R I U$, Gyalóka is recorded as the find-spot of the monuments. For Peresznye see Lörincz 2001, 203, ad n 151 with literature.

${ }^{4}$ Holder 1980: 144.

${ }^{5}$ For the dating of the inscriptions see Lörincz 2001: 205, $\mathrm{n}^{\circ}$ 157-158 (Belegiš and Acumincum); Alföldy 2002 $271, n^{\circ} 13$ (Páty).

${ }^{6}$ Knight 1991: 190 connects its relocation to the division of Illyricum.

${ }^{7}$ Mráv 2010-2013: 68.

${ }^{8}$ On the Amber road see Mócsy 1974: 94-95.

${ }^{9}$ Spaul 1995: 66 considered Arrabona as the unit's permanent camp. The fort at Gyalóka was garrisoned by a detachment of of experienced older soldiers with the task of patrolling the western approach to the main camp at Arrabona.
} 
between 25 and $30 \mathrm{AD}^{10}$

The ala Pannoniorum remained in Pannonia until the beginning of Vespasian's reign. It was transferred to Moesia Inferior, where it garrisoned the fortress of Troesmis. ${ }^{11}$ Sometime during the reign of Trajan, the ala Pannoniorum changed its garrison province once again. It remains uncertain whether it was transferred to Dacia or Numidia. ${ }^{12}$ Epigraphic evidence strongly suggests that it was sent back to Pannonia during the second half of the second century AD. According to modern scholars, the transfer of the ala Pannoniorum to its former garrison province occurred after the Marcomannic War of Marcus Aurelius. ${ }^{13}$ The site of its fortress has not been determined. Adduced epigraphic evidence, i. e. the two votive inscriptions from Belegiš (CIL III 15138/3) and Slankamen (CIL III 3252=10241), strongly suggests that it was located in the south-eastern parts of the province. Considering the distribution of auxiliary units on the lower stretch of the Pannonian Danube, one might presume that the ala Pannoniorum was stationed in Cusum (modern Petrovaradin). The garrisons of other auxiliary castella on that section of the limes are all accounted for. Cornacum (modern Sotin) was occupied by the cohort II Aurelia Dacorum milliaria equitata, Malata/Bononia (modern Banoštor) probably by the ala I Flavia Augusta Britannica milliaria civium Romanorum, Acumincum by the cohort I Campanorum voluntariorum civium Romanorum, Rittium (modern Surduk) by the ala I Augusta Ituraeorum sagittariorum and Burgenae by the cohort I Thracum civium Romanorum. ${ }^{14}$ The late Roman stone fortress of Cusum was garrisoned by the equites Delmatae. ${ }^{15}$ Archaeological evidence from Petrovaradin implies the existence an earlier castellum at the site, possibly occupied by the Ala Pannoniorum. ${ }^{16}$

Epigraphic evidence from Dalmatia and Pannonia provides scant information on the origins of soldiers serving in the ala Pannoniorum. During its first sojourn in Illyricum, the regiment was replenished by Spaniards and Pannonians. Cloutius, son of Clutamus, who served under Augustus in Dalmatia, ${ }^{17}$ had been enlisted among the Susarri, one of the twenty two tribes of the Astures (CIL III 2016=8577). The ethnonym is recorded on the famous edict from El Bierzo, issued by Augustus in $15 \mathrm{BC}$. The emperor granted perpetual immunity to the inhabitants of the castellum Paemeiobriga, belonging to the gens of the Susarri, because they had, unlike other tribes from the north-western Spain, remained loyal to Rome in the years between 26 and $22 \mathrm{BC}$. He also decreed that they should keep the lands they were holding when the short-lived province of Transduriana was governed by Lucius Sestius Quirinalis (22-19 BC). All the duties of the Paemiobrigenses were

${ }^{10}$ Mráv 2010-2013: 76. On the history of the ala Pannoniorum and its movements in the first century AD see Wagner 1938: 57; Mócsy 1962: 619-620; Wilkes 1969: 140-141; Alföldy 1987: 244; Lőrincz 2001: 22.

${ }^{11}$ Lörincz 2001: 22; Matei-Popescu 2010: 191.

${ }^{12}$ Roxan, Holder 2003: 433, ad $\mathrm{n}^{\circ} 222$ have opted for Dacia, stating that the unit was back in Moesia Inferior in $125 \mathrm{AD}$, after it had been amalgamated with the ala I Gallorum. Spaul 1995: 68 has presumed that the regiment was transferred to Numidia.

${ }^{13}$ Lörincz 2001: 22; Alföldy 2002: 271.

${ }^{14}$ Lörincz 2001: 104-105. For the possibility that the ala Pannoniorum garrisoned Cusum cf. Dušanić 1968: 102; Visy 2003: 145.

${ }^{15}$ Not. dig. Occ. XXXII 32, 34. Cf. Wilkes 2005: 207.

16 Visy 2003: 145.

${ }^{17}$ Holder 1980: 283, $\mathrm{n}^{\circ} 621$. 
transferred to the inhabitants of the castellum Aiiobrigiaecum, belonging to the gens of the Gigurri. ${ }^{18}$ Apparently, the Susarri and the Gigurri were neighbors, the former living to the northeast of the latter. ${ }^{19}$ Since the Gigurri were one of the Asturian tribes mentioned by Pliny the Elder, ${ }^{20}$ Susarri probably also belonged to the Astures. ${ }^{21}$ Cloutius' home is recorded in ablative as Curunniace. Although modern scholars followed Hübner in identifying it with Curunda in the territory of the Asturian Zoelae, ${ }^{22}$ it seems logical to presume that it was located in the region inhabited by the Susarri, i. e. the vicinity of modern Bembibre and the valley of the river Boeza and its tributaries. ${ }^{23}$

Two Spanish recruits are attested in the ala Pannoniorum during its stay in Pannonia. They served in the fort of Strebersdorf, under Tiberius, along with their comrade Abilus, son of Turancus (RIU 216). ${ }^{24}$ Pentius, son of Dovider or Doviderus, is styled Aligantiensis. Although the exact location of Aligantia remains undetermined, it seems that it was situated in the north-western parts of the Iberian peninsula. The name Pentius is considered as Cantabro-Asturian. ${ }^{25}$ One should also note that a Cantabrian princeps, attested on an inscription from modern Valmartino, bore the name Doviderus. ${ }^{26}$ Bovegius, son of Veminus, was recruited in Lancia. Two towns bearing that name are attested in Lusitania, and one in the territory of the Astures. ${ }^{27}$ It is impossible to determine which of them was the hometown of Bovegius. Abilus, son of Turancus, presumably belonged to the indigenous population of the Iberian Peninsula as well. His origin is implied by the name Abilus, attested on an inscription mentioning a man from the Cantabrian town of Vadinia. ${ }^{28}$ Abilus' home was recorded as Lucocadiacus. He was enlisted in Lucocadia, a settlement presumably located in the conventus Asturum or in the western Lusitania. ${ }^{29}$ The presence of Spaniards in the ala Pannoniorum is not surprising, considering the warlike disposition of various Iberian tribes. Spanish auxiliaries were already prominent in the Roman army in the late Republican period. ${ }^{30}$ After the final subjugation of the northwestern regions of the Iberian Peninsula in 19 BC auxiliary regiments were formed throughout the Spanish provinces. ${ }^{31}$ A reference concerning the recruitment of Spaniards under Augustus is found in Strabo. The geographer states that the Cantabrian tribes who live near the sources of the Iber were subdued by Augustus and they take field for the

\footnotetext{
${ }^{18}$ Alföldy 2000: 177-205. In addition to the edict, the name of Susarri is attested on a tessera hospitalis found at Torre de Cabreira and dated to $28 \mathrm{AD}$ (AE 2000, 748).

${ }^{19}$ Alföldy 2000: 189.

${ }^{20}$ Plin. HN III 28.

${ }^{21}$ Luján Martinez 2008: 74 presumes that the Susarri could have been Gallician or Asturian.

${ }^{22}$ Hübner 1901: 1894. Cf. e. g. Wilkes 1969: 475; Albertos Firmat 1974: 432; Costabile, Licandro 2002, 45, n. 47. For a different opinion see Luján 2009, 243; Correa 2002: 256 and 257, n. 16.

${ }^{23}$ On the territory of Susarri see Alföldy 2000: 187; Solana Sáinz 2004: 50.

${ }^{24}$ For the date see Holder 1980: 283, ${ }^{\circ} 622$.

${ }^{25}$ Vallejo 2013: 99.

${ }^{26}$ AE 1997, 875.

${ }^{27}$ Schulten 1924: 620-621; Galsterer 1971: 63.

${ }^{28}$ Vives 1971, 5431. On Vadinia and its territory see González Rodríguez 2011: 95.

${ }^{29}$ P. Le Roux 2007: 205-206, n. 51.

${ }^{30}$ Saddington $1982,152$.

${ }^{31}$ Holder 1980: 113.
} 


\section{Romans. $^{32}$}

Epigraphic evidence indicates that the ala Pannoniorum was regularly replenished by Pannonian recruits during its first sojourn in Pannonia. Scilus, son of Bato, was conscripted among the Breuci under Tiberius or Claudius (RIU 256). ${ }^{33}$ Two soldiers, enlisted at the same time as Scilus,${ }^{34}$ came from the tribe of Colapiani - a horseman whose name is not preserved, son of Cralus (RIU 258), and Bato, son of Bulus (RIU 255). According to J. E. H. Spaul, Bato was recruited in the Claudian colony of Apri and he was Macedonian, as well as his decurion and heir Scenus, son of Scenobarvus. ${ }^{35}$ His origo, recorded as COLAP on his tombstone, should be read as Colap(ianus) for two reasons. First, Bato could have been recruited under Tiberius, at the time when the colony of Apri had not yet been founded. Second, his service took place in the period when auxiliary units were for the most part conscripted in the provinces and areas where they had been raised. ${ }^{36}$ Pannonian soldiers in the ala Pannoniorum were all drafted in the southern parts of the province, which had come under the Roman influence and rule during the last decades of the Republican period and under Augustus. Living along the middle and lower Colapis, ${ }^{37}$ Colapiani were subdued at the end of Octavian's Illyrian war, after the fall of Segestica in $35 \mathrm{BC}^{38}$ Breuci inhabited the area to the south of Andizetes and the confluence of the rivers Drava and Danube. Their territory, stretching to the Sava in the south ${ }^{39}$ was conquered during the bellum Pannonicum (13-9 BC). ${ }^{40}$ Reflecting on the Pannonians in the ala Pannoniorum, one should bear in mind that the local recruitment in the province started under Tiberius. The earliest datable testimony is provided by a military diploma issued before $54 \mathrm{AD}$ to a certain Dases, veteran of the cohort II Hispanorum scutata. ${ }^{41} \mathrm{He}$ was enlisted before 29 AD among the Cornacates. Their territory extended to the east of Breuci and Andizetes, between the rivers Sava and Danube. ${ }^{42}$

Onomastic evidence provides certain hints concerning the origin of a number of other soldiers of the ala Pannoniorum during its first sojourn in Illyricum. Some of them bore Illyrian and others Celtic names. The decurion and heir of the Colapian Bato was of Illyrian descent (RIU 255). His name Scenus and the name of his father Scenobarvus/Scenobarbus belong to the Illyrian onomastic corpus. ${ }^{43}$ The same holds true for both the decurion and heir of the other Colapian recruit (RIU 258). The officer's name Artus (or Artius) is considered to be Illyrian, ${ }^{44}$ as well as the heir's patronymic

\footnotetext{
${ }^{32}$ Strabo III 3, 8=C 156 .

${ }^{33}$ Holder 1980: 284, $\mathrm{n}^{\circ} 624$.

${ }^{34}$ Holder 1980: 284, ${ }^{\circ}$ 625-626.

${ }^{35}$ Spaul 1995: 72.

${ }^{36}$ On the pattern of recruitment see Holder 1980: 114-115, 123

${ }^{37}$ Grbić 2014: 189-190.

38 Šašel Kos 2005: 441; Dzino 2010: 114.

${ }^{39}$ Zaninović 2003: 48.

${ }^{40}$ Mócsy 1962: 540-541; Dzino 2010: 131-134.

${ }^{41}$ CIL XVI 2.

42 Mócsy 1959: 76.

${ }^{43}$ Krahe 1929: 101; Mayer 1957: 312-313; Mócsy 1959: 189; Alföldy 1969: 289.

${ }^{44}$ Krahe 1929: 11; Mayer 1957: 63; Mócsy 1959: 164.
} 


\section{Plassarus. ${ }^{45}$}

Judging by onomastic evidence, two soldiers of the ala Pannoniorum were of Celtic descent. The first one was Deculus, decurion and one of the two heirs of the Breucus Scilus (RIU 256). He bore a Gaulish name. ${ }^{46}$ The other soldier, whose name is only partially preserved as [- - ]cus, was the son of a certain Elmallus (RIU 217). K. Kraft believed that he was enlisted among the German tribe of Chatti. His opinion was based on the reading of the second row of the soldier's epitaph proposed by Th. Mommsen. The word f(ilius) was followed by the restitution [C]attus. ${ }^{47}$ However, on the photograph, published in the first volume of Römische Inschriften Ungarns, the last three letters of the row - TTVS - are clearly preceded by the upper part of an I. Consequently, the word after f(ilius) was [.]ittus. It should be considered as part of the soldier's name and, following B. Lörincz, restituted as [C]ittus. ${ }^{48}$ The Celtic origin of the soldier named [- - - ]cus Cittus is revealed by his patronymic. The name Elmallus, not attested elsewhere in the western provinces or northern Italy, ${ }^{49}$ belongs to the Celtic onomastic corpus. The element -mallus is found in various Gaulish personal names (e. g. Cantomallus, Caramallus), as well as a single name-Mallus. It is derived from the word mallos, meaning "lazy, slow". ${ }^{50}$

To sum up. The ala Pannoniorum garrisoned Illyricum twice during the first three centuries of the Roman empire. Its first sojourn in Dalmatia and Pannonia occurred during the reign of the Julio-Claudian dynasty. At first, the regiment was stationed in Dalmatia, possibly in the vicinity of Salona. At the beginning of Tiberius's reign, it was transferred to Pannonia. Its earliest fort there was located near modern Strebersdorf, protecting the section of the famous Amber road between Savaria and Scarbantia. A couple of decades later, the ala Pannoniorum was relocated to the north, to the fortress of Arrabona. It remained there until the beginning of Vespasian's reign, when it was transferred once again, this time to Troesmis in Moesia Inferior. The ala Pannoniorum left the Danubian provinces some time under Trajan. It was relocated either to Numidia or Dacia. It was brought to the Danube once again, after the Marcommanic War of Marcus Aurelius. It might have garrisoned Cusum in Pannonia Inferior. Epigraphic evidence from Dalmatia and Pannonia reveals two main areas of recruitment of the ala Pannoniorum during its first sojourn in Illyricum. Fresh conscripts were drafted among the warlike tribes of the Iberian Peninsula. The home of one soldier was Lancia in the land of the Astures or one of the two homonymous towns in Lusitania. A duplicarius was enlisted among the Asturian Susarri, while two soldiers presumably came from the north-western parts of the Iberian Peninsula. Judging by epigraphic evidence, the ala Pannoniorum was replenished by Pannonians as well. Inscriptions mention two Colapiani and one Breucus. Both tribes inhabited regions that were under the Roman rule or influence since the end of the republican period or the time of Augustus. The Colapiani were subdued during Octavian's Illyrian war (35 BC) and the Breuci during the bellum Pannonicum (13-9 BC). Epigraphic evidence dated to the

\footnotetext{
${ }^{45}$ Krahe 1929: 92; Mócsy 1959: 184.

${ }^{46}$ Mócsy 1959: 243, ${ }^{\circ} 158 / 7$.

${ }^{47}$ Kraft 1951: 156, n 472. Cf. Mommsen, CIL III 4228.

${ }^{48}$ Lörincz 2001: 204, n 152.

49 OPEL II 115.

${ }^{50}$ Delamarre 2003: 214-215.
} 
first sojourn of the ala Pannoniorum in Illyricum provides some information on the regiment's ethnic composition and recruitment. Inscriptions belonging to the time when the unit garrisoned Pannonia Inferior unfortunately offer no clues to its soldiers' origins.

\section{REFERENCES:}

Albertos Firmat, M. 'Hallazgos Arqueológicos y Epigráficos en Villar del Buey (Zamora)', Zephyrus 25, 1974, 429-433.

Alföldy, G. Die Personennamen in der römischen Provinz Dalmatia, Heidelberg: Carl Winter Universitätsverlag, 1969.

Alföldy, G. 'Die Auxiliartruppen der Provinz Dalmatien', in: M. Speidel (ed.), Römische Heeresgeschichte. Beiträge 1962-1985, Amsterdam: Verlag J. C. Gieben, 1987, 239-297.

. 'Das neue Edikt des Augustus aus El Bierzo', Zeitschrift für Papyrologie und Epigraphik 133, 2000, 177-205.

. 'Epigraphica Pannonica I. Inschriften aus der näheren Umgebung von Aquincum', Zeitschrift für Papyrologie und Epigraphik 140, 2002, 263-277.

Correa, J. A. 'Svssaros (Svsarres), ceca visigoda', Zeitschrift für Papyrologie und Epigraphik 138, 2002, 256-258.

Costabile F. and Licandro, O. Tessera Paemeiobrigensis, Roma: L'Erma di Bretschneider, 2002.

Delamarre, X. Dictionnaire de la langue gauloise. Une approche linguistique du vieux-celtique continental, Paris: Editions Errance, 2003.

Dušanić, S. „Rimska vojska u istočnom Sremu“, Zbornik radova Filozofskog fakulteta (Beograd) 10-1, 1968, 87-113. [Душанић, С. „Римска војска у источном Срему“, Зборник радова Филозофског факултета (Београд) 10-1, 1968, 87-113.]

Dzino, D. Illyricum in Roman Politics 229 BC-AD 68, Cambridge: Univerisity Press, 2010.

Galsterer, H. Untersuchungen zum römischen Städtewesen auf der Iberischen Halbinsel, Berlin: Walter De Gruyter and Co., 1971.

González Rodríguez, M. C. 'En torno a la expresión de la origo en el noroeste hispano: el caso de los Cántabros vadinienses como ejemplo de integración cívica', in: J. M. Iglesias Gil and A. Ruiz Gutiérrez (eds.), Viajes y cambios de residencia en el mundo romano, Santander: PUbliCan, Ediciones de la Universidad de Cantabria, 2011, 93-118.

Grbić, D. Plemenske zajednice u Iliriku. Predurbane administrtivne structure u rimskim provincijama između Jadrana i Dunava (I-III vek), Beograd: Balkanološki institute, 2014. [Грбић, Д. Племенске заједнице у Илирику. Предурбане административне структуре у римским провинцијама између Јадрана и Дунава (I-III век), Београд: Балканолошки институт, 2014.]

Holder, P. A. Studies in the Auxilia of the Roman Army from Augustus to Trajan, Oxford: Archaeopress, 1980.

Hübner, E. 'Curunda', in: RE IV, Stuttgart: J. B. Metzlerscher Verlag, 1901, 1893-1894.

Knight D. J. 'The Movements of the Auxilia from Augustus to Hadrian', Zeitschrift für Papyrologie und Epigraphik 85, 1991, 189-208.

Kraft, K. Zur Rekrutierung der Alen und Kohorten an Rhein und Donau, Bern: A. Francke AG Verlag, 1951.

Krahe, H. Lexicon altillyrischer Personennamen, Heidelberg: Carl Winter's Universitätsbuchhandlubg 1929.

Lörincz, B. Die römischen Hilfstruppen in Pannonien während der Prinzipatszeit. Teil I: Die 
Inschriften, Wien: Forschunggesellschaft Wiener Stadtarchäologie, 2001.

Luján Martinez, E. 'Gallician Place-names Attested Epigraphically’, in: J. L. García Alonso (ed.), Celtic and Other Languages in Ancient Europe, Salamanca: Universidad de Salamanca, 2008, 65-82.

Luján, E. R. 'Pueblos celtas y no celtas de la Galicia antigua: Fuentes literarias frente a fuentes epigráficas, Estudios de lenguas y epigrafía antiguas 9, 2009, 219-250.

Matei-Popescu, F. The Roman Army in Moesia Inferior, Bucharest: Conphys Publishing House 2010.

Mayer, A. Die Sprache der alten Illyrer, Wien: Österreichischen Akademie der Wissenschaften, 1957.

Mócsy, A. Die Bevölkerung von Pannonien bis zu den Markomannenkriegen, Budapest: Ungarische Akademie der Wissenschaften, 1959.

. 'Pannonia', in: RE Suppl. IX, Stuttgart: Alfred Druckenmüller Verlag, 1962, 515-775.

. Pannonia and Upper Moesia: A History of the Middle Danube Provinces of the Roman Empire, London/Boston: Routledge and Kegan Paul, 1974.

Mráv, Zs. 'The Roman Army along the Amber Road between Poetovio and Carnuntum in the 1st Century A.D. - Archaeological Evidence', Communicationes Archaeologicae Hungariae, 2010-2013, 49-100.

Papazoglu, F. Srednjobalkanska plemena u predrimsko doba. Tribali, Autarijati, Dardanci, Skordisci i Mezi, Beograd: Equilibrium, 2007.

Le Roux, P. 'Géographie péninsulaire et épigraphie romaine' in: P. Moret and G. Cruz Andreotti and P. Le Roux (eds.), La invención de una geografía de la Península Ibérica II. La época imperial, Malaga/Madrid: Casa de Velázquez, 20007, 197-219.

Roxan, M. and Holder, P. Roman Military Diplomas V, London: Institute of Classical Studies, 2003.

Saddington, D. B. The Development of the Roman Auxiliary Forces from Caesar to Vespasian (49 B.C.-A.D. 79), Harare: University of Zimbabwe, 1982.

Schulten, A. 'Lancia', in: RE XII, Stuttgart: J. B. Metzlerscher Verlagsbuchhandlung, 1924, 620621.

Solana Sáinz, J. M. 'La pacificación de los pueblos del norte de Hispania', Hispania antiqua: revista de historia antigua 28, 2004, 25-70.

Spaul, J. E. H. 'Ala I Pannoniorum - One or Many?', Zeitschrift für Papyrologie und Epigraphik $105,1995,63-73$.

Šašel Kos, M. Appian and Illyricum, Ljubljana: Narodni muzej Slovenije, 2005.

Vallejo, J. M. 'El concepto de área onomástica: el caso de los Astures', Studia Historica. Historia Antigua 31, 2013, 89-113.

Visy, Zs. The Roman Army in Pannonia. An Archaeological Guide of the ripa Pannonica, Pécs: Teleki László Foundation, 2003.

Vives, J. Inscripciones latinas de España romana, Barcelona: Universidad de Barcelona, Departamentos de Filología Latina, 1971.

Wagner, W. Die Dislokation der römischen Auxiliarformationen in den Provinzen Noricum, Pannonien, Moesien und Dakien von Augustus bis Gallienus, Berlin: Junker und Dünnhaupt, 1938.

Wilkes, J. J. Dalmatia, London: Routledge and Kegan Paul Limited, 1969. . 'The Roman Danube: An Archaeological Survey', The Journal of Roman Studies 95, 2005, 124-225.

Zaninović, M. 'Breuci od Sirmija do Marsonije', Opuscula archaeologica 27, 2003, 443-449. 


\section{СНЕЖАНА ФЕРЈАНЧИЋ}

Универзитет у Београду, Филозофски факултет

\section{ALA PANNONIORUM У ВOЈСЦИ ИЛИРИКА}

\section{Резиме}

Провинција Илирик, која је обухватала огроман простор између Јадранског мора и Дунава, основана је кратко време после Октавијановог Илирског рата (35-33. године пре н.е.). У току делматско-панонског устанка (6-9. године н.е.) или непосредно по његовом завршетку, подељена је на Горњи Илирик (Illyricum Superius) и Доњи Илирик (Illyricum Inferius), тј. Далмацију и Панонију. Војну посаду ових провинција чинило је неколико легија, као и велики број помоћних одреда, међу којима је била и ala Pannoniorum. Натписи ове јединице, нађени на неколико локалитета у Далмацији и Панонији, омогућавају да се реконструише њена историја и пружају извесне податке о њеној регрутацији.

Ala Pannoniorum је у Илирику боравила два пуга током Принципата. Први пут је то било за владе династије Јулијеваца-Клаудијеваца, а други пут после Маркоманских ратова Марка Аурелија. На почетку свог првог боравка у Илирику, ala Pannoniorum је била стационирана у Далмацији. Почетком Тиберијеве владе, око 15. године, пребачена је у Панонију. Најпре је била стационирана у утврђењу поред Штреберсдорфа, а затим у Арабони. Почетком Веспазијанове владавине, ala Pannoniorum је прекомандована у Доњу Мезију. Под Трајаном је пребачена у Дакију или Нумидију, да би се у Илирик вратила у другој половини II века. На ову претпоставку указују натписи наше јединице који су нађени на три локалитета у Доњој Панонији (Пати на територији Аквинкума, Белегиш и Сланкамен) и датовани на крај II или почетак III века. Имајући у виду распоред помоћних одреда на најјужнијем делу панонског лимеса, препостављамо да је ala Pannoniorum могла бити стационирана у Кузуму.

Натписи из Далмације и Паноније откривају два главна извора регрутације наше јединице током њеног првог боравка у Илирику. Један део регрута чинили су људи уновачени на Иберијском полуострву. Међу њима срећемо једног човека из Ланције (није јасно да ли је реч о граду на територији Астура или једном од два истоимена града у Лузитанији), те једног припадника Сусара, који су припадали племену Астура. Још двојица војника могла су бити уновачена на северо-западу Иберијског полустрва. На то указују њихова имена, као и имена њихових очева. Присуство хиспанских регрута у али на дунавском лимесу није нимало изненађујуће. Припадници ратоборних иберских племена играли су значајну улогу у помоћним одредима римске војске још од доба позне републике. Други значајан извор војника била су домородачка племена јужне Паноније. У али Pannoniorum су посведочена двојица Колапијана и један Бреук. Њихова племена живела су у областима које су под римским утицајем и влашћу биле од последњих деценија републике или Августове владавине. Колапијани су покорени у току Октавијановог Илирског рата, када је пала Сегестика (35. године пре н.е.), а Бреуци током панонског рата (13-9. године пре н.е.). Епиграфски материјал везан за други боравак але Pannoniorum у Илирику, тј. у Доњој Панонији, не пружа никакве податке ни индиције о пореклу њених војника.

Кључне речи: Илирик, Дамација, Панонија, ala Pannoniorum, регрутација, Шпанци, Панонци. 